\title{
Implementasi Fuzzy - Service Quality Terhadap Tingkat Kepuasan Layanan Mahasiswa
}

\section{Implementation of Fuzzy - Service Quality for Student Service Level of Satisfaction}

\author{
Nanny Fajar Kartika ${ }^{1}$, Suprayogi ${ }^{2}$ \\ 1,2JurusanTeknik Informatika, Universitas Dian Nuswantoro Semarang \\ Jl. Imam Bonjol 205-207 Semarang 50131 \\ 1nannyfajark@ gmail.com, ${ }^{2}$ suprayogismg@gmail.com
}

\begin{abstract}
Abstrak
Setiap mahasiswa tentunya ingin mendapatkan kualitas pelayanan pendidikan yang optimal dan sesuai dengan harapan mahasiswa. Oleh karena itu, perlu dilakukan pengukuran untuk mengetahui seberapa besar tingkat puas atau tidaknya mahasiswa terhadap kualitas layanan pendidikan yang diberikan oleh pihak universitas. Pengolahan data dilakukan dengan menghitung nilai fuzzifikasi, defuzzifikasi, serta perhitungan nilai GAP antara persepsi dan harapan mahasiswa. Dengan hasil yang diperoleh, dapat membantu pihak Universitas Dian Nuswantoro dalam meningkatkan kinerja dan kualitas pelayanan dalam hal bidang akademik, dan sarana prasarana. Dari hasil pengolahan data menggunakan metode fuzzy-servqual (service quality) diperoleh hasil yang memiliki gap terbesar dan perlunya ada perhatian khusus dan perbaikan dari pihak universitas yaitu gap dengan nilai terbesar adalah atribut kenyamanan, kebersihan dan ketersediaan lahan parkir dengan nilai gap sebesar (-2.55), kemudian peringkat kedua yaitu pada atribut ketersediaan bandwidth hotspot dengan nilai gap (-2.523), selanjutnya atribut ketersediaan green area dengan nilai gap (-2.521). Dari hasil perhitungan Gap secara keseluruhan menunjukkan bahwa nilai gap negative dengan arti yaitu persepsi atau layanan yang diterima mahasiswa tidak sesuai dengan harapan mahasiswa.
\end{abstract}

Kata kunci-Fuzzy, Service Quality, Gap, Kualitas Pelayanan

\begin{abstract}
Each student will want to get optimal quality of educational services and in accordance with studentsexpectation. Therefore, it is necessary to measure the level of satisfaction for student service quality of education provided by the university. Data processing is done by calculating the value of fuzzification, defuzzification, as well as the calculation of the value of GAP between the perceptions and expectations of students. With the results obtained, it can help the Dian Nuswantoro University in improving the performance and quality of service in terms of academics and infrastructure. From the results of data processing using fuzzy-servqual (service quality) obtained results that the biggest gap and the need for special attention and improvement of the university authorities that gap with the greatest value are the attributes of comfort, cleanliness and parking lots availability with a gap value of (-2.55), then the second is the attribute of hotspot bandwidth availability with a gap value (-2.523), the availability of green areas is the next attribute with a value gap (-2.521). From the calculation of the overall
\end{abstract}

38 Jurnal Ilmiah SISFOTENIKA 
Gap shows that the negative gap with the sense of perception or services received in accordance with students expectations are not satisfied.

Keywords - Fuzzy, Service Quality, Gap, Service Quality

\section{PENDAHULUAN}

Pelayanan akademik dapat di nilai baik dan berkualitas didasarkan dengan kinerja baik dari tenaga pengajar, tenaga administrasi maupun fasilitas yang ada. Sehingga memberikan tingkat kepuasan kepada banyaknya mahasiswa dengan layanan yang diberikan dan sesuai dengan apa yang diharapkan mahasiswa untuk meningkatkan kualitas layanan akademik[1]. Dan juga secara tidak langsung akan memberikan manfaat yang signifikan kepada Universitas. Pelayanan dalam bidang akademik yang baik sangatlah diharapkan oleh para mahasiswa. Dalam segala segi kehidupan dalam sebuah perguruan tinggi sangat banyak hal-hal yang terjadi terutama komitmen sebuah penyedia jasa pendidikan tinggi dalam memberikan layanan kepada para mahasiswa ataupun calon mahasiswa, sejak mereka masih menjadi calon mahasiswa hingga menjadi alumni[2].Mahasiswa merupakan unsur utama sebagai pengguna jasa pendidikan yang akan menilai apakah pelayanan yang mereka terima sudah sesuai dengan yang mereka harapkan yaitu timbal balik dari biaya yang sudah dikeluarkan.

Penilaian akan suatu layanan jasa didasarkan pada persepsi individu. Persepsi adalah proses yang digunakan individu mengelola dan menafsirkan kesan indera mereka dalam rangka memberikan makna kepada lingkungan mereka[3].Permasalahan yang dibahas pada penelitian ini adalah bagaimana pihak universitas memberikan layanan untuk mahasiswa seperti akses internet yang memadai, laboratorium komputer yang baik, perpustakaan yang nyaman dan koleksi bukunya yang lengkap, parkir kendaraan yang nyaman dan aman serta layanan fasilitas yang lain, agar dapat memberikan suatu rekomendasi yang menguntungkan bagi universitas, dalam hal ini memberikan kepuasan bagi mahasiswa serta mencegah ketidakpuasan mahasiswa atas semua layanan fasilitas kampus[4].

Dari permasalahan uraian diatas dapat dilakukan analisis kepuasaan mahasiswa di Universitas Dian Nuswantoro. Universitas Dian Nuswantoro Semarang merupakan perguruan tinggi swasta terkemuka di Semarang, jumlah mahasiswa pada FIK yang lebih dari 1000 mahasiswa tersebut mendasari munculnya pertanyaan apakah kualitas layanan kampus yang diberikan pihak Universitas sudah sesuai dengan apa yang dijanjikan kepada mahasiswa, Dari survey yang dilakukan di Universitas Dian Nuswantoro dengan melakukan kuisioner terhadap mahasiswa dengan sampel 20 mahasiswa didapatkan hasil dari 20 mahasiswa,lebih banyak mahasiswa merasa tidak puas akan layanan yang diberikan dibandingkan dengan mahasiswa yang sudah merasa puas. Dari hasil kuisioner ini munculnya ketidakpastian antara kepuasan atau ketidakpuasan mahasiswa dengan pelayanan yang diberikan oleh pihak universitas. Maka diperoleh rumusan masalah yaitu bagaimana mengimplementasikan Metode Fuzzy Service Quality untuk mengukur tingkat kepuasan mahasiswa terhadap layanan di Universitas Dian Nuswantoro.

Tujuan penelitian untuk menyelesaikan masalah yang diungkapkan di atas serta keterbatasan pengetahuan yang dimiliki penulis, maka penulis membuat ruang lingkup penelitian dengan pembahasan mengunakan metode Fuzzy Service Quality.

Berdasarkan rumusan masalah yang diuraikan diatas, maka tujuan dari penelitian ini adalah menerapkan metode Fuzzy Service Quality terhadap tingkat kepuasan layanan mahasiswa Untuk meningkatkan kualitas layanan Universitas Dian Nuswantoro. 


\section{METODE PENELITIAN}

Fuzzy Service Quality adalah Teori himpunan fuzzy yang memberikan sarana untuk mempresentasikan ketidakpastian dan merupakan alat untuk pemodelan ketidakpastian yang berhubungan dengan kesamaran, ketidakpastian dan kekurangan informasi mengenai elemenelemen tertentu dari problem yang dihadapi [5]. Pada prinsipnya himpunan fuzzy adalah perluasan dari himpunan crisp, yaitu himpunan yang membagi sekelompok individu ke dalam dua kategori, anggota dan bukan anggota[6].

Metode servqual adalah metode untuk mengukur kualitas pelayanan yang terdiri dari 5 dimensi kualitas pelayanan. Servqual dipandang memenuhi syarat validitas secara statistik karena frekuensi penggunaanya yang tinggi[7]. Kelebihan menggunakan metode servqual yaitu lebih mudah untuk menangkap persepsi atau pandangan dari hasil pengumpulan data dengan kuisioner. Dan juga unggul untuk menentukan variabel-variabel mana yang harus lebih diperhatikan untuk meningkatkan pelayanan [8]. Dalam hal ini untuk mengukur tingkat kepuasaan digunakannya metode servqual dikarenakan di antara berbagai model pengukuran kualitas pelayanan, servqual merupakan metode yang paling banyak digunakan [9]. Sehingga dapat dengan mudah untuk menentukan variabel-variabel mana yang harus lebih ditingkatkan, untuk meningkatkan kualitas layanan dan lebih tepat untuk mengukur tingkat kepuasan mahasiswa sehingga pihak Universitas dapat mengetahuai fasilitas apa yang dianggap penting dan berpengaruh untuk meningkatkan kepuasan mahasiswa dan juga meningktakan kualitas layanan akademik[8,9].

Gabungan dengan menggunakan metode fuzzy servqual ini mencegah masalah pandangan individu yang tidak pasti atau (samar) terhadap penilaian persepsi dan harapan yang diinginkan. Selain itu juga diperlukan pendekatan yang rasional dengan membuat suatu interval dalam ruang yang mampu mempresentasikan penilaian yang tidak pasti [10].

\subsection{Langkah langkah Algoritma Fuzzy Service Quality}

Melakukan pengkonversian nilai skala kedalam fuzzy number dari variabel input terhadap masing-masing atribut. Dalam interpretasinya, ketika responden memilih nilai 4 (puas). Artinya, ia menilai, bahwa 3 dan 5 adalah nilai minimum dan maksimum (atau dapat diartikan, bahwa responden mempertimbangkan mana dari tiga hipotesis, biasa saja, puas dan sangat puas yang menurut mereka paling mewakili). Dalam metode fuzzy skor 4 sesuai dengan nilai $(3,4,5)$. Demikian pula skor 5 sesuai dengan $(4,5,5)$ sehingga didapatkan fuzzy number dari setiap nilai, sebagai berikut.

Tabel 1 Fuzzy Number

\begin{tabular}{ll}
\hline Skala Likert & Fuzzy Number \\
\hline 1 & $(1,1,2)$ \\
\hline 2 & $(1,2,3)$ \\
\hline 3 & $(2,3,4)$ \\
\hline 4 & $(3,4,5)$ \\
\hline 5 & $(4,5,5)$ \\
\hline
\end{tabular}

Setelah dilakukan pengkonversian maka selanjutnya dilakukan proses komposisi fuzzy number $\left(a_{m i}, b_{m i}, c_{m i}\right)$ untuk persepsi dan harapan terhadap setiap atribut dengan menggunakan prinsip operasi aritmatika pada himpunan TFN. Proses komposisi ini digunakan untuk 
mendapatkan nilai komposisi dari fuzzy number seluruh responden dengan menggunakan arithmatic mean untuk memperoleh skor bobot rata-rata:

$$
a_{m}=\frac{\left(a_{m 1}+a_{m 2}+a_{m 3} \ldots+a_{m i}\right)}{N} b_{m}=\frac{\left(b_{m 1}+b_{m 2}+b_{m 3} \ldots+b_{m i}\right)}{N} c_{m}=\frac{\left(c_{m 1}+c_{m 2}+c_{m 3} \ldots+c_{m i}\right)}{N}
$$

Nilai komposisi fuzzy number dari masing-masing atribut yang didapat, selanjutnya adalah dilakukan proses deffuzzifikasi dengan metode centroid untuk mendapatkan besaran nilai tunggal dari masing-masing atribut. Dengan menggunakan metode titik tengah (Center Of Area) yang akan diformulasikan sebagai berikut:

$$
z=\frac{\int \mu(z) z d z}{\int \mu(z) d z}
$$

Proses diatas diulang sampai seluruh atribut yang ada di persepsi dan harapan mendapatkan nilai deffuzzifikasi atau nilai tunggal tunggal.Nilai gap performance dihitung dari selisih antara nilai deffuzzifikasi yang ada antara skor variabel persepsi dan variabel harapan dari masing-masing atribut. Dengan rumus sebagai berikut :

$$
(G a p)=(\text { Nilai persepsi }- \text { Nilai harapan })
$$

Setelah proses defuzzyfikasi dilakukan, maka didapatkan nilai tunggal yang representatif. Selanjutnya dilakukan analisis yang meliputi :

1. Analisis kinerja/kenyataan terhadap pelayanan yang diberikan.

2. Analisis harapan mahasiswa terhadap pelayanan.

Analisis gap kualitas pelayanan antara kinerja/ kenyataan dan harapanlayanan per atribut dan per dimensi.

\subsection{Metode Pengumpulan Data}

a. Survey

Dalam penelitian ini melakukan pengamatan langsung terhadap layanan - layanan di Universitas Dian Nuswantoro atau objek yang akan diteliti serta melakukan daftar-daftar pertanyaan atau pernyataan untuk disebarkan kepada responden.

\section{b. Kuesioner}

Kuesioner dalam penelitian ini sebagai acuan unutk melakukan pengumpulan data yang akan disebarkan kepada responden (mahasiswa) yang berisikan daftar pertanyaan atau pernyataan untuk diisi yang berkaitan dengan kualitas layanan.

c. Wawancara

Pada teknik ini disaat responden melakukan pengisian atau sesudah melakukan pengisian kuisioner juga disertai melakukan wawancara langsung terhadap responden yang berkaitan dengan kualitas layanan fasilitas Universitas Dian Nuswantoro dan tingkat kepuasan mahasiswa.

d. Studi Pustaka

Hal ini yang bertujuan untuk melakukan atau memperoleh data sebagai data pendukung maupun tambahan dengan memperoleh data dengan cara tidak langsung atau disebut dengan data sekunder yaitu yang bersumber berupa literatur, buku, jurnal, dan informasi dari internet yang berkaitan dengan penelitian ini yaitu mengetahui tingkat kepuasaan konsumen untuk meningkatkan kualitas pelayanan. 


\section{Implementasi Fuzzy Service Quality ...}

\subsection{Penyusunan Kuesioner}

Pada penyusunan kuesioner didasarkan dari data sekunder yang menghasilkan 26atribut kualitas layanan (item). Variabel kualitas layanan meliputi sebagai berikut :

Tabel 2 Atribut Pertanyaan

\begin{tabular}{|c|c|}
\hline NO & ATRIBUT PERTANYAAN \\
\hline $\boldsymbol{I}$ & TANGIBLE (BUKTI FISIK) \\
\hline 1 & Kenyamanan, kebersihan, dan keamanan ruang kuliah \\
\hline 2 & Kelengkapan,kenyamanan, kebersihan lab komputer \\
\hline 3 & Kelengkapan,kenyamanan, kebersihan perpustakaan \\
\hline 4 & Kelengkapan,kenyamanan, kebersihan sarana olahraga \\
\hline 5 & Kenyamanan, kebersihan dan ketersediaan lahan tempat parkir \\
\hline 6 & Kenyamanan,kebersihan, kelengkapan dan keamanan ruang Unit Kegiatan Mahasiswa \\
\hline 7 & Ketersediaan bandwidth hot spot \\
\hline 8 & Kenyamanan, kebersihan dan keamanan Ruang Ibadah (Masjid) \\
\hline 9 & Kenyamanan,kelengkapan, kebersihan dan keamanan Ruang Tunggu waktu jedaa kuliah \\
\hline 10 & Ketersediaan Green Area \\
\hline 11 & Kenyamanan, kelengkapan, dan keamanan alat transportasi umum (Bus Kampus) \\
\hline 12 & Kenyamanan, kelengkapan dan kebersihan ruang Toilet-WC \\
\hline II & RELIABILITY (KEHANDALAN) \\
\hline$\overline{13}$ & Kurikulum dan proses pembelajaran \\
\hline 14 & Kualitas dan kualifikasi Dosen \\
\hline 15 & Susana perkuliahaan dan praktikum \\
\hline 16 & Materi yng disampaikan dosen jells dan mudah dimengerti \\
\hline 17 & Kualitas alumni \\
\hline$\underline{I I I}$ & RESPONSIVENESS (DAYA TANGGAP) \\
\hline$\overline{18}$ & $\overline{\text { Respon dan kecepatan dalam pelayanan }}$ \\
\hline 19 & Kualitas layanan secara keseluruhan dalam menunjang kelancaran aktivitas perkuliahan \\
\hline 20 & Relevansi, Akurasi dan tepat waktu SIADIN (Sistem Informasi Akademik) \\
\hline$\underline{I V}$ & ASSURNCE (JAMINAN) \\
\hline$\overline{21}$ & Pengetahuan dan keterampilan yang diperoleh setelah kuliah \\
\hline 22 & Penguasaan terhadap bidang pekerjannya \\
\hline 23 & Keamanan kampus \\
\hline$\underline{V}$ & EMPHATY (PEDULI) \\
\hline 24 & Inisiatif dalam membantu \\
\hline 25 & Keramahan, kesopanan dan sikap dalam pelayanan \\
\hline 26 & Komunikasi yang baik antara mahasiswa dengan pihak jurusan terjalin \\
\hline
\end{tabular}

2.4 Prosedur penelitian

Prosedur penelitian dapat dilihat pada Gambar 1 :

\section{Jurnal Ilmiah SISFOTENIKA}




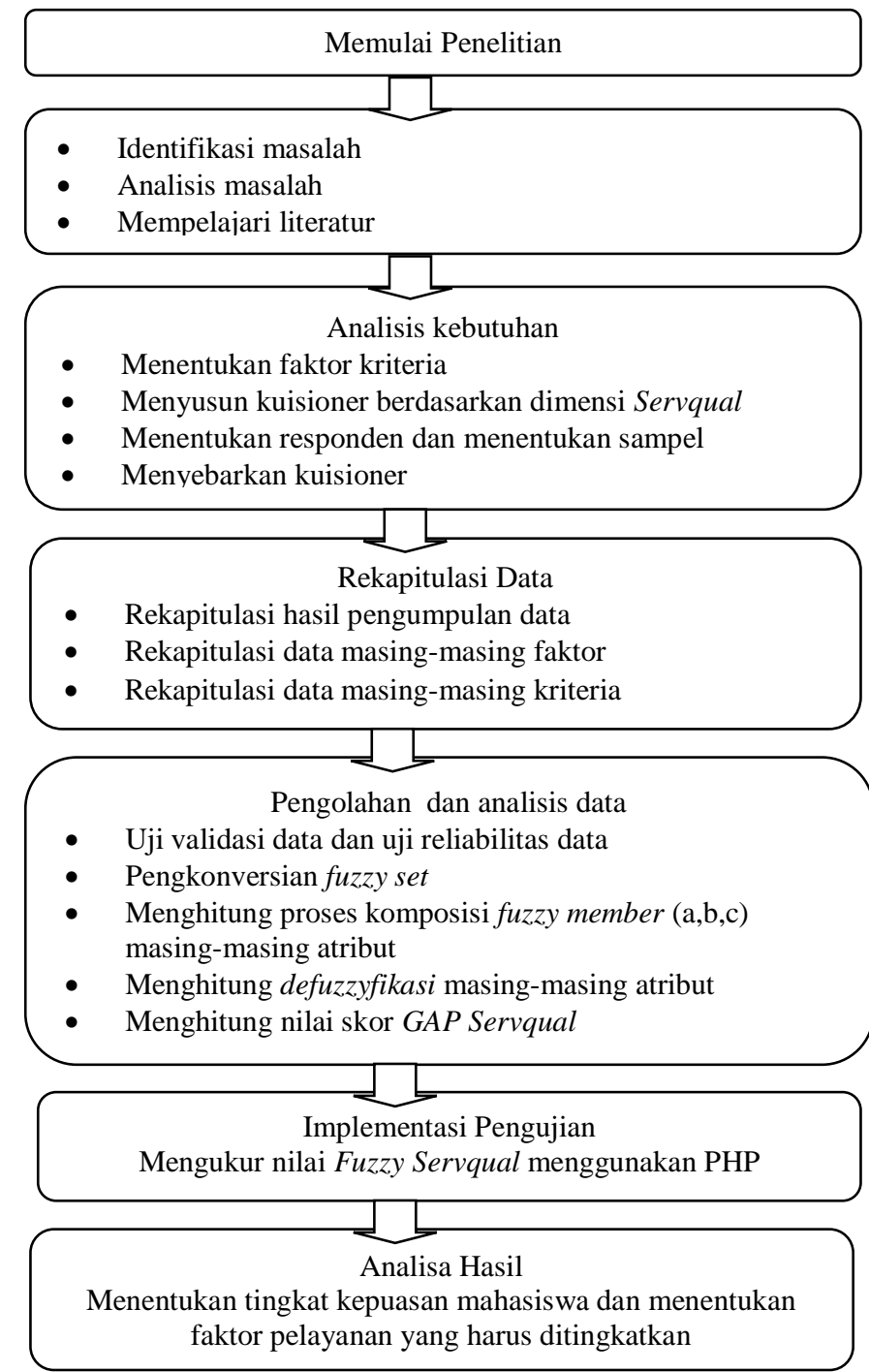

Gambar 1 Prosedur Penelitian

\section{HASIL DAN PEMBAHASAN}

Tahapan awal yang dilakukan pada penelitian ini adalah persiapan data, yang diperoleh dari Responden mahasiswa universitas Dian nuswantoro. Data yang diperoleh adalah data kuesioner dari 26 atribut pertanyaan yang sudah dikelompokkan 5 dimensi servqual.

3.1 Pengolahan Fuzzy servqual

Pada pengolahan fuzzy service qulity terdapat 3 tahap dalam Teori Triangular Fuzzy Number yakni penentuan fuzzy set, fuzzyfikasi, dan defuzzyfikasi.

1. Penentuan fuzzy set 


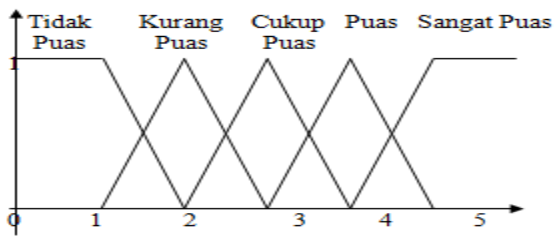

Gambar 2 Fuzzy Set

Dengan demikian, nilai yang kita gunakan dalam penentuan bobot (skor) yang kita gunakan untuk penghitungan nilai fuzzyfikasi adalah; tidak puas dengan nilai $0,1,2$ nilai untuk kurang puas 1, 2, 3 kemudian cukuppuas adalah 2, 3, 4 dan nilai puas 3, 4, 5 kemudian untuk nilai sangat puas 4,5 .

\section{Fuzzyfikasi}

Proses komposisi ini digunakan untuk mendapatkan nilai komposisi dari fuzzy number seluruh responden dengan menggunakan arithmatic mean untuk memperoleh skor bobot ratarata.

\section{Defuzzyfikasi}

$$
\begin{aligned}
& a_{m}=\frac{\left(a_{m 1}+a_{m 2}+a_{m 3} \ldots+a_{m i}\right)}{N} b_{m}=\frac{\left(b_{m 1}+b_{m 2}+b_{m 3} \ldots+b_{m i}\right)}{N} c_{m}= \\
& \frac{\left(c_{m 1}+c_{m 2}+c_{m 3} \ldots+c_{m i}\right)}{N}(4)
\end{aligned}
$$

Selanjutnya proses defuzzyfikasi untuk mendapatkan besaran nilai tunggal dari masingmasing atribut. Dengan menggunakan metode titik tengah (Center Of Area) yang akan diformulasikan sebagai berikut:

$$
z=\frac{\int \mu(z) z d z}{\int \mu(z) d z}(5)
$$

\subsection{Implementasi Program}

\subsubsection{Tampilan Awal}

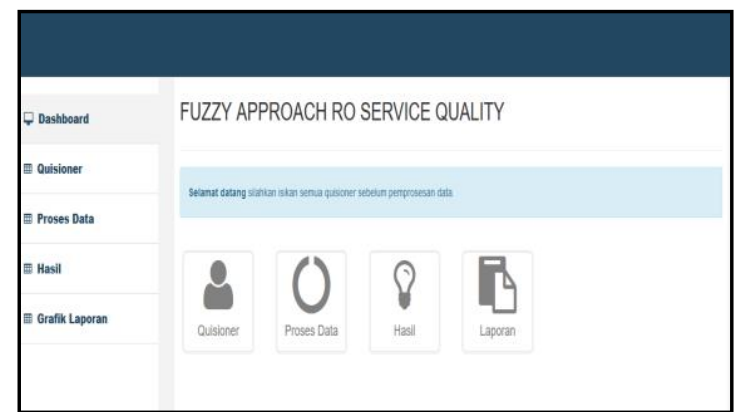

Gambar 3 Tampilan Awal

Pada halaman ini, admin dapat menambahkan data kuesioner mahasiswa .dalam halaman ini terdapat menu Kuesioner, proses data, hasil dan garfik laporan. Data Identitas kuesioner yang diinputkan berupa informasi mengenai nama, dan Nim mahasiswa. 


\subsubsection{Tampilan Kuesioner}

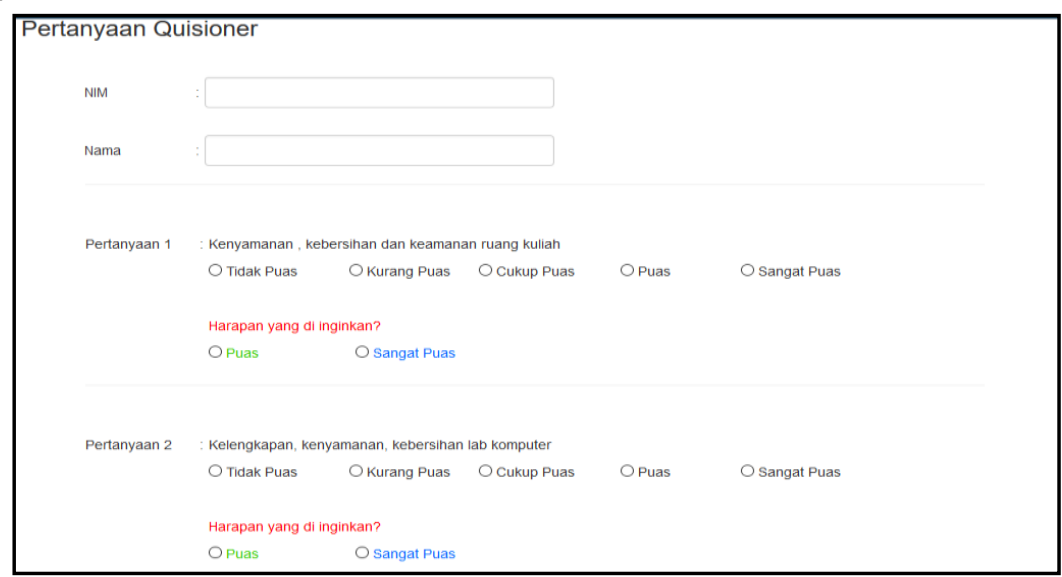

Gambar 4 Tampilan Kuesioner

Pada halaman ini, admin dapat menginputkan kuesioner yang berupa 26 atribut pertanyan yang disediakan. Pada variabel persepsi terdapat pilihan tidak puas, kurang puas, cukup puas, puas dan sangat puas. Dan pada variabel harapan terdapat pilihan Penting dan sangat penting. Setelah melakukan penginputan kuesioner sebanyak 26 atribut pertanyaan maka data berhasil disimpan.

\subsubsection{Tampilan Proses Data}

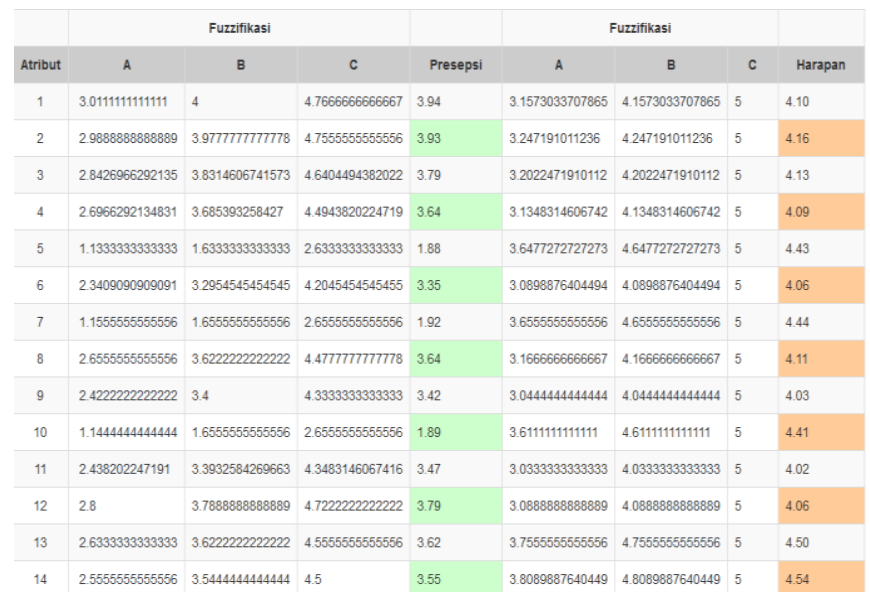

Gambar 5 Tampilan Proses Data

Pada tampilan ini, admin dapat memproses data yang awalnya dengan menentukan nilai fuzzy number $(a, b$ c) yang kemudian di lakukan fuzzyfikasi pada nilai $(a, b, c)$ dan selanjutnya defuzzyfikasi pada variabel Persepsi dan variabel harapan. 
Implementasi Fuzzy Service Quality ...

\subsubsection{Tampilan Pengolahan Data}

\begin{tabular}{|r|l|l|l|l|}
\hline No & \multicolumn{1}{|c|}{ Atribut } & Presepsi & Harapan & \multicolumn{1}{|c|}{ Gap } \\
\hline 1 & Kenyamanan, kebersihan dan keamanan ruang kuliah & 3.94 & 4.10 & -0.16 \\
\hline 2 & Kelengkapan, kenyamanan, kebersihan lab komputer & 3.93 & 4.16 & -0.24 \\
\hline 3 & Kelengkapan, kenyamanan dan kebersihan perpustakaan & 3.79 & 4.13 & -0.35 \\
\hline 4 & Kelengkapan, kenyamanan dan kebersihan sarana olanraga & 3.64 & 4.09 & -0.45 \\
\hline 5 & kenyamanan, kebersihan dan ketersediaan lahan tempat parkir & 1.88 & 4.43 & -2.55 \\
\hline 6 & $\begin{array}{l}\text { kenyamanan, kebersihan, kelengkapan dan keamanan ruang unit kegiatan } \\
\text { mahasiswa }\end{array}$ & 3.35 & 4.06 & -0.71 \\
\hline 7 & ketersediaan bandwidth hotspot & 1.92 & 4.44 & -2.52 \\
\hline 8 & kenyamanan, kebersihan dan keamanan ruang ibadah (masjid) & 3.64 & 4.11 & -0.47 \\
\hline 9 & $\begin{array}{l}\text { kenyamanan, kelengkapan, kebersihan dan keamanan ruang tunggu waktu } \\
\text { jeda kuliah }\end{array}$ & 3.42 & 4.03 & -0.61 \\
\hline 10 & ketersedian green area & 1.89 & 4.41 & -2.52 \\
\hline
\end{tabular}

Gambar 6 Tampilan Pengolahan Data

Dalam tampilan ini admin dapat melihat hasil proses data dengn metode Fuzzy Servqual. Didapatkan hasil nilai defuzzyfikasi masing-masing variabel persepsi dan variabel harapan. Dan selanjutnya juga menampilkan nilai Gap dengan mengurangi nilai variabel persepsi dengan variabel harapan setiap masing-masing atribut pertanyaan. Sehingga dapat dengan mudah untuk menganalisa kepuasaan mahasiwa.

\subsubsection{Tampilan Rank Gap}

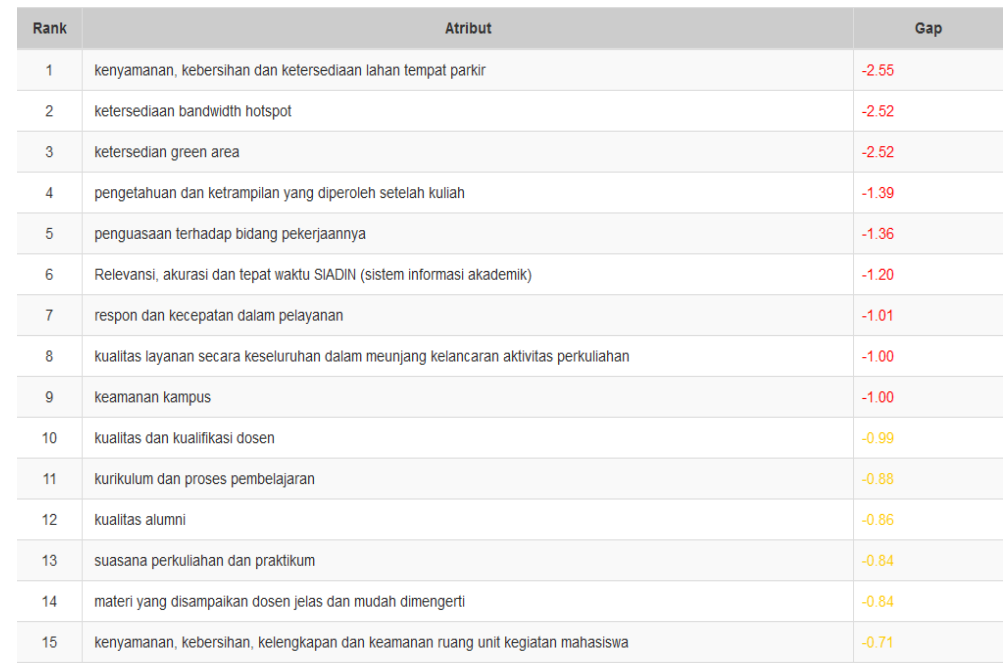

Gambar 7 Tampilan Rank Gap

Pada halaman ini, terdapat tampilan urutan atau ranking Gap tiap atribut pertanyaan. Urutan ranking gap yaitu diperoleh dari nilai gap terkecil kemudian diurutkan sampai nilai gap terbesar. Urutan nilai gap atau ranking gap terbesar yang menujukan bahwa banyaknya 
mahasiswa yang belum merasa puas dengan pelayanan Universitas. Dan perlunya perhatian khusus dari pihak universitas.

\subsubsection{Tampilan Grafik Hasil Gap}

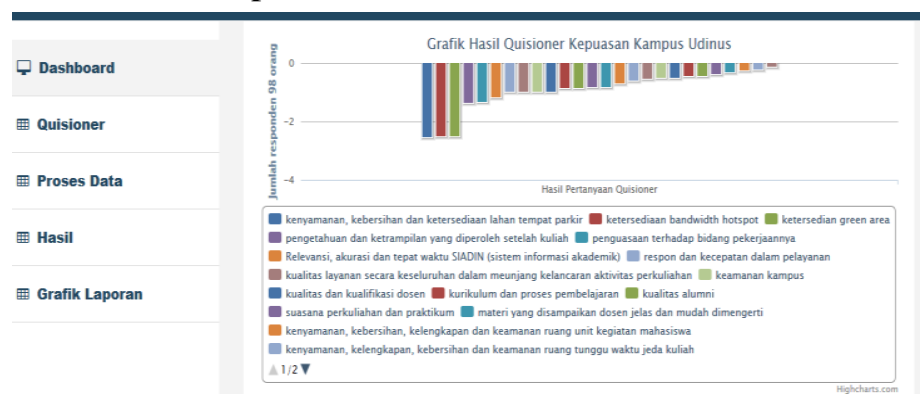

Gambar 8 Tampilan Grafik Hasil Gap

Pada halaman grafik, dapat menampilkan grafik tiap atribut pertanyaan sesuai dengan nilai gap. Nilai gap terkecil yang menunjukan adanya ketidaksesuain antara persepsi dengan harapan mahasiswa.

\subsection{Analisis Pengolahan Data}

a. Penghitungan Nilai Servqual ( Gap ) Per Atribut antara Persepsi danHarapan Mahasiswa Berikut ini adalah 5 kriteria dengan nilai servqual terbesar yang harus menjadi perhatian Universitas Dian Nuswantoro, yaitu :

Tabel 3 Nilai Servqual Terbesar

\begin{tabular}{llc}
\hline no & Atribut & Gap \\
\hline 1 & Ketersediaan lahan parkir & $-2,55$ \\
\hline 2 & Ketersediaan bandwitdh hostpot & $-2,52$ \\
\hline 3 & Ketersediaan green area & $-2,52$ \\
\hline 4 & Pengetahuan dan keterampilan yang diperoleh setelah kuliah & $-1,39$ \\
\hline 5 & Penguasaan terhadap bidang pekerjaanya & $-1,36$ \\
\hline
\end{tabular}

Dari urutan 5 kriteria diatas yang perlu mendapatkan perhatian lebih dan evaluasi perbaikan dari pihak Universitas Dian Nuswantoro, karena kelima kriteria tersebut sangat dirasakan kurang oleh para mahasiswa.

b. Penghitungan Nilai Servqual ( Gap ) Per Dimensi antara Persepsi danHarapan Mahasiswa

Tabel 4Perhitungan Nilai Servqual

Dimensi Gap Rank


Implementasi Fuzzy Service Quality ...

\begin{tabular}{lll}
\hline Tangibles & $-0,88391$ & 4 \\
\hline Reliability & $-1,03125$ & 3 \\
\hline Responsivenes & $-1,1141$ & 2 \\
\hline Assurance & $-1,2680$ & 1 \\
\hline Emphaty & $-0,76003$ & 5 \\
\hline
\end{tabular}

Hasil perhitungan gap per dimensi menunjukkan bahwa Dimensi Assurance menempati ranking yang pertama dengan nilai $-1,2680$. Hal ini menunjukkan bahwa kriteria-kriteria dalam Dimensi Assurance sangat perlu atau lebih diprioritaskan untuk dilakukan perbaikan.

c. Penghitungan Nilai Servqual(Gap) Keseluruhan antara Persepsi danHarapan Mahasiswa.

Hasil perhitungan gap secara keseluruhan menunjukkan bahwa nilai gap negatif sebesar $-3,3754$, berarti apa yang diharapkan Mahasiswa belum sesuai dengan apa yang diperoleh mahasiswa Universitas Dian Nuswantoro.

\section{KESIMPULAN}

Dari uraian dan pembahasan, maka dapat diambil beberapa kesimpulan yaitu :

a. Berdasarkan pengolahan dan analisa data fuzzy-servqual per atribut dapat diketahui bahwa tingkat kualitas pelayanan di Universitas Dian Nuswantoro secara keseluruhan memiliki nilai negatif. Sehingga mahasiswa belum puas terhadap jasa pelayanan yang diberikan oleh pihak Universitas Dian Nuswantoro.

b. Atribut yang memiliki nilai gap tertinggi yaitu ketersediaan lahan tempat parkir. Dengan demikian atribut ini merupakan atribut yang banyak dikeluhkan mahasiswa sehingga perlu segera dilakukan perbaikan. Sedangkanatribut yang ranking terendah adalah kenyamanan, kebersihan dan keamanan ruang kuliah.

\section{SARAN}

a. Dalam peningkatan pelayanan pada mahasiswa, hasil penelitian ini dapat dijadikan sebagai bahan pertimbangan pihak Universitas Dian Nuswantoro untuk memperbaiki kualitas layanan.

b. Sistem yang digunakan untuk mengimplementasikan metode fuzzy service quality ini masih belum sempurna. Dan masih banyak yang perlu dikembangkan.

\section{DAFTAR PUSTAKA}

[1]. H. Irawan , "10 Prinsip Kepuasan Pelanggan," in 10 Prinsip Kepuasan Pelanggan, Jakarta, PT.Elex Media Komputindo Gramedi., 2002.

[2]. I. N. Rinala, I. M. Yudana and I. N. Natajaya, "Pengaruh Kualitas Pelayanan Akademik Terhadap Kepuasan dan Loyalitas Mahasiswa pada Sekolah Tinggi Pariwisata Nusa Dua Bali," vol. 4, 2013.

[3]. R. S, Organization Behavior (Edisi Indonesia) Jilid II, Jakarta: PT. Prenhallindo, 2003.S. Kusumadewi dan S. Hartati, Neuro-Fuzzy; Integrasi Sistem Fuzzy \& Jaringan Syaraf Edisi 2, Yogyakarta: Graha Ilmu, 2010.

48 Jurnal Ilmiah SISFOTENIKA 
[4]. H. Turnip, M. Situmorang and . R. , "Analisis Kepuasan Mahasiswa Terhadap Kualitas Pelayanan dengan Metode Fuzzy Service Quality," Saintia Matematika, vol. 2, pp. 163$171,2014$.

[5]. S. Kusumadewi and P. , "Aplikasi Logika Fuzzy untuk Pendukung Keputusan," in Aplikasi Logika Fuzzy untuk Pendukung Keputusan, Yogyakarta, Graha Ilmu, 2010.

[6]. Rose, "Hospital Service Quality: a Managerial Challenge," International Journal of Health Care Quality Management, vol. 17 no 3, pp. 146-149, 2004.

[7]. Brysland and curry, "Service Improvement in public services using SERVQUAL," Managing Service Quality, vol. 11 no 6, pp. 389-401, 2001.

[8]. B. Harto, "Analisis Tingkat Kepuasan Pelanggan Dengan Pendekatan Fuzzy Servqual dalam Upaya Peningkatan Kualitas Pelayanan," vol. 3 no.1, 2015.

[ 9]. W. M, "Using SERVQUAL To assess customer satisfaction with public sector services," Managing Service Quality, vol. 11 no 5, pp. 380-388, 2001.

[10]. S. A. Vica and N. W. Setyanto, "Peningkatan Kulitas Pelayanan Nasabah BPJS Ketenagakerjaan Denagn Metode Fuzzy-Servqual Dan Indeks PGCV," Desember 2013. 